\title{
Hydrochemistry and Groundwater Quality Assessment in Mafraq Province, Jordan
}

\author{
Ali Obeidat ${ }^{1}$, Mahmoud Alawneh ${ }^{2}$ \\ ${ }^{1}$ Department of Geology, Faculty of Science, The University of Jordan, Amman, Jordan \\ ${ }^{2}$ Ministry of Water and Irrigation, Amman, Jordan \\ Email: aalobeid2000@yahoo.com, mahmoudalawneh_2014@yahoo.com
}

How to cite this paper: Obeidat, A. and Alawneh, M. (2019) Hydrochemistry and Groundwater Quality Assessment in Mafraq Province, Jordan. Open Access Library Journal, 6: e5365.

https://doi.org/10.4236/oalib.1105365

Received: April 2, 2019

Accepted: April 27, 2019

Published: April 30, 2019

Copyright $\odot 2019$ by author(s) and Open Access Library Inc.

This work is licensed under the Creative Commons Attribution International License (CC BY 4.0).

http://creativecommons.org/licenses/by/4.0/

(c) (i) Open Access

\begin{abstract}
The acceptable water quality standard varies based on the intended use of water. Therefore, the standard will be dramatically decreased while moving from Drinking, domestic, industrial and agricultural purposes. Water quality modeling software Aquachem and ArcGIS10.3 were used to analyze data sets of 12 samples from four different wells located around the Mafraq area in order to investigate its suitability for drinking. The results revealed that hydrochemistry of groundwater recorded a wide range in total dissolve solid (TDS) and the chloride is found to be most predominating. Generally, groundwater in the University and Zatari areas has high concentrations of nitrate. The major element's data were plotted on the Piper's diagram for working of hydrogeochemical facies. Mixed $\mathrm{CaMgCl}$ are the most prominent facies. The $\mathrm{pH}$ part of the drive diagram reveals that groundwater in the study area is alkaline and electrical conductivity of most of samples lies in the range of drinking water standards adopted in Jordan.
\end{abstract}

\section{Subject Areas}

Hydrology

\section{Keywords}

Water Quality, Hydrogeological Facies, Water-Rock Interaction, Groundwater Evaluation

\section{Introduction}

The Mafraq City at the North East of Jordan was selected as the study area based on the availability of data. It is the largest of the country's four governmental provinces in terms of area. The area is located between latitudes $32.25^{\circ}$ to $32.00^{\circ}$ 
north and longitudes $36.00^{\circ}$ to $36.20^{\circ}$ east, as shown in the location map given in Figure 1. It is the eastern extension of the Jordanian Plateau with deserts, valleys and plains. The elevation of the province increased from very low in the extreme east at the average rainfall from 20 to $200 \mathrm{~mm}$. Due to growing industry in cities and increasing urbanization, water demand is growing and will need to depend largely on the groundwater. This continued exploitation of groundwater results in declining water table and deterioration in water quality. It is crucial to evaluate the quality and quantity of groundwater for its suitable utilization.

\section{Geology}

[1] and [2] studied the geology of this area, Rocks exposed from the upper Cretaceous to lower tertiary in Mafraq, which is stratigraphically divided into three major zones namely the Muwaqqar Chalky Mar (MCM), the Umm Rijam Chalk (URC) and Wadi Shallala Chalk (WSC). The Eruptive basalt zone covers the northeastern side of the study area as it is shown in Figure 2.

Groundwater in Mafraq area in both confined and unconfined aquifers in all basins and sub-basins are generally flows from catchment boundaries to the axis of valleys and then follows the general trend of surface drainage. A similar study was carried out by [3] by investigating the groundwater quality for Azraq and Harrana basin for the same Aquifers in south eastern Jordan.

\section{Material and Methods}

All groundwater contains inorganic and organic constituents in solution due to the interaction of the groundwater with the surrounding environment. A baseline for quality criteria, including chemical, physical, and biological properties,

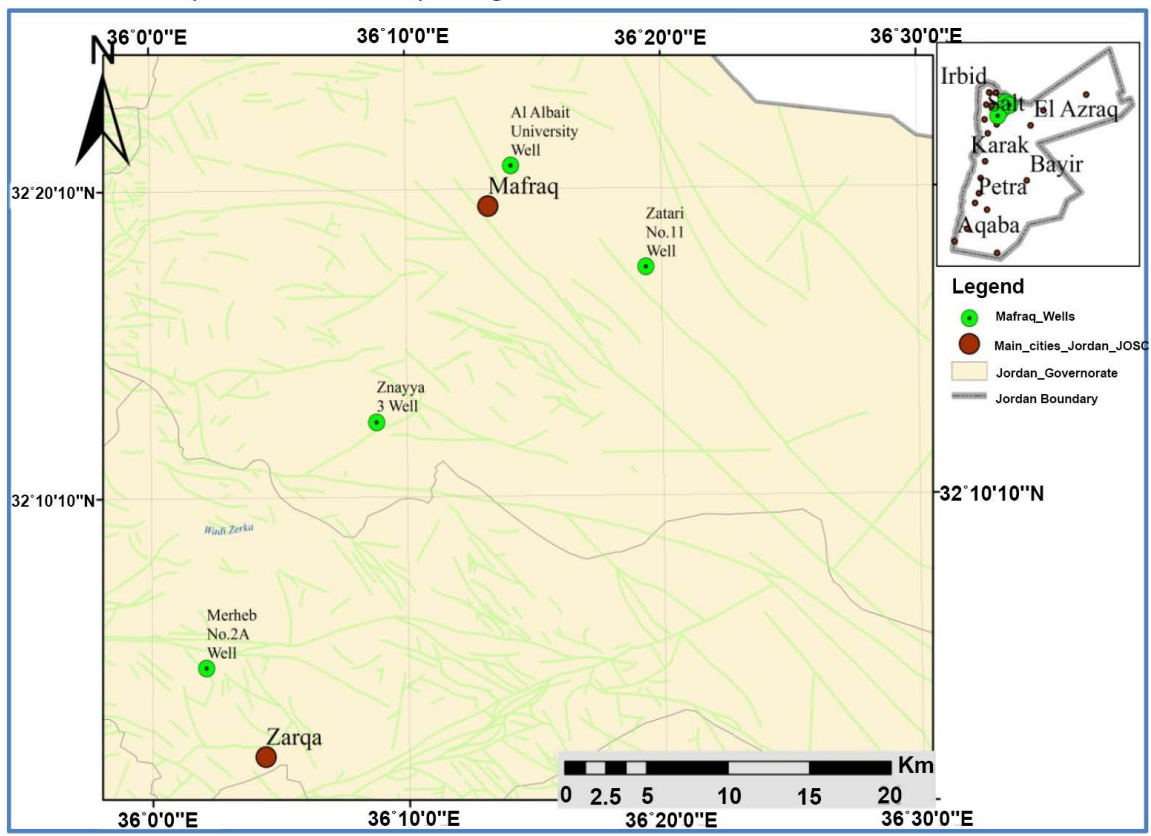

Figure 1. Location of the tested wells in Mafraq and its surrounds. 


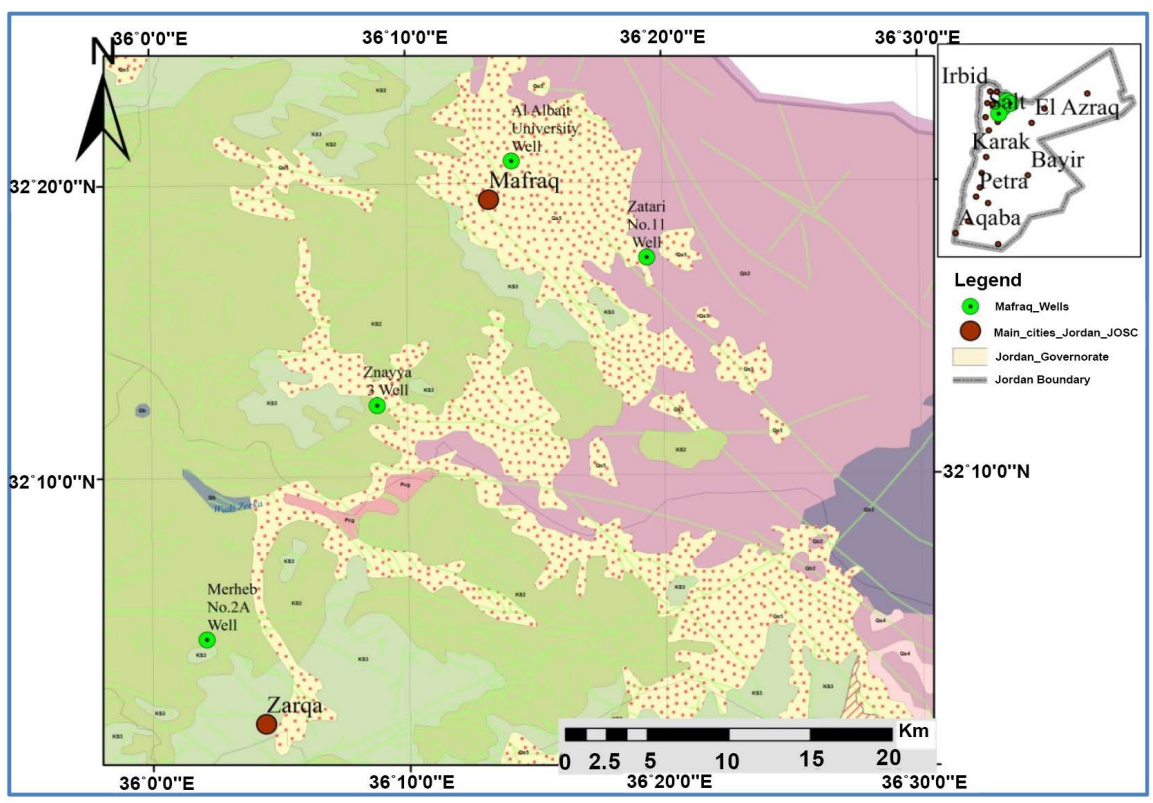

Figure 2. Geology Map of the study area after bender 1975, cretaceous-green, fluvial deposits—doted, basalt lava flow-pink color.

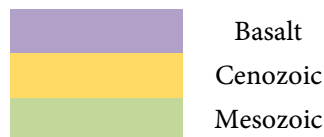

as well as standard methods of reporting and comparing results of water analyses must be established for new development areas. The aim of the hydrochemical studies is to distinguish the geochemical properties that control the dissolved constituents in water and establish the distribution of some contaminants aquifers result from human activities. The quality of a water supply depends upon its purpose; thus, the needs of drinking, industrial and irrigation water vary widely. Representative groundwater samples from the four locations in the Mafraq Province aquifer were obtained, the wells selected on the basis of geographical distribution. Aquachem and ArcGIS10.3 software programs have been used to manage create and graphically display the water quality data.

\section{Water Samples Preservation and Laboratory Analysis}

From the studied area, the selected wells are used for drinking, irrigation and domestic use. All the water samples were collected in the period between 2010 and 2015 and it were analyzed for 11 physical and chemical water quality parameters including: $\mathrm{pH}, \mathrm{EC}$, and major cations (calcium, carbonate, magnesium sodium and potassium) and major anions (chloride, sulfate, Nitrate and bicarbonate) in laboratory of MWI using Standard Methods for the Examination of Water and analysis as per American Public Health Association [4].

\section{Results and Discussion}

The statistical comparison of the range, mean and standard deviations (SD) of 
concentrations of chemical constituents of groundwater samples are given in Table 2. The chemical analyses of the groundwater showed large variations of dissolved ions concentrations with high salinity in some samples. The standard deviations for potassium and bicarbonate are greater than their averages due to the large variations for these constituents. Electrical conductivity showed large spatial variations between 280 and $3125 \mu \mathrm{S} / \mathrm{cm}$, with a mean value of 1025.58 $\mu \mathrm{S} / \mathrm{cm}$ indicating a very wide range of fresh to lightly saline water.

\subsection{Water Physical Parameters}

The most common physical parameters of water: $\mathrm{pH}$, electrical conductivity EC and total dissolved solids (TDS) have been determined. The $\mathrm{pH}$ values in the study area range between 7.5 and 7.9 with mean value of 7.7.

The very pure distilled water is theoretically insulator due to the absence of any ions which act as charge carriers. So, EC distribution indicates low values of EC in the middle and northern areas of Mafraq and with gradient increases toward the south and northern-east regions.

\subsection{Water Chemical Parameters}

The abundance of major ions largely depends upon the nature of rocks, climatic conditions and mobility. The ion distribution is also influenced by the infinite complex surface and subsurface physicochemical environments, To asses these geochemical processes the collected water samples are chemically analyzed for the major cations $\left(\mathrm{Na}^{+}, \mathrm{K}^{+}, \mathrm{Ca}^{2+}\right.$ and $\left.\mathrm{Mg}^{2+}\right)$ and major anions $\left(\mathrm{Cl}^{-}, \mathrm{SO}_{4}^{2-}, \mathrm{NO}_{3}^{-}\right.$ and $\mathrm{HCO}_{3}^{-}$).

\section{Graphical Presentation of Hydrochemical Data}

During circulation of water in rocks and soils, ions leached out and dissolve in groundwater. The geological formations, water-rock interaction and relative mobility of ions are the prime factors influencing the geochemistry of the groundwater. Because of chemical analysis results of water in form of tables may be difficult to interpret. The graphic representations are used to discuss the water-rock interaction in the study area. Hydrogeological facies were worked out by developing Scholler, Stiff, Piper and Durov diagrams.

\subsection{Schoeller}

[5] Diagram is also used to present average chemical composition of Mafraq groundwater. The relative tendency of ions in $\mathrm{mg} / \mathrm{l}$ shows $\mathrm{Na}>\mathrm{Mg}>\mathrm{Ca}>\mathrm{K}$ and $\mathrm{Cl}>\mathrm{HCO}_{3}>\mathrm{SO}_{4}$. Schoeller diagram in Figure 3 below present the average composition of major cations anions of the groundwater for Mafraq province.

\subsection{Trilinear Diagram (Piper Diagram)}

Piper Diagrams [6] are a combination anion and cation triangles that lie on a common baseline. Diamond shape between them can be used to make a conclusion 


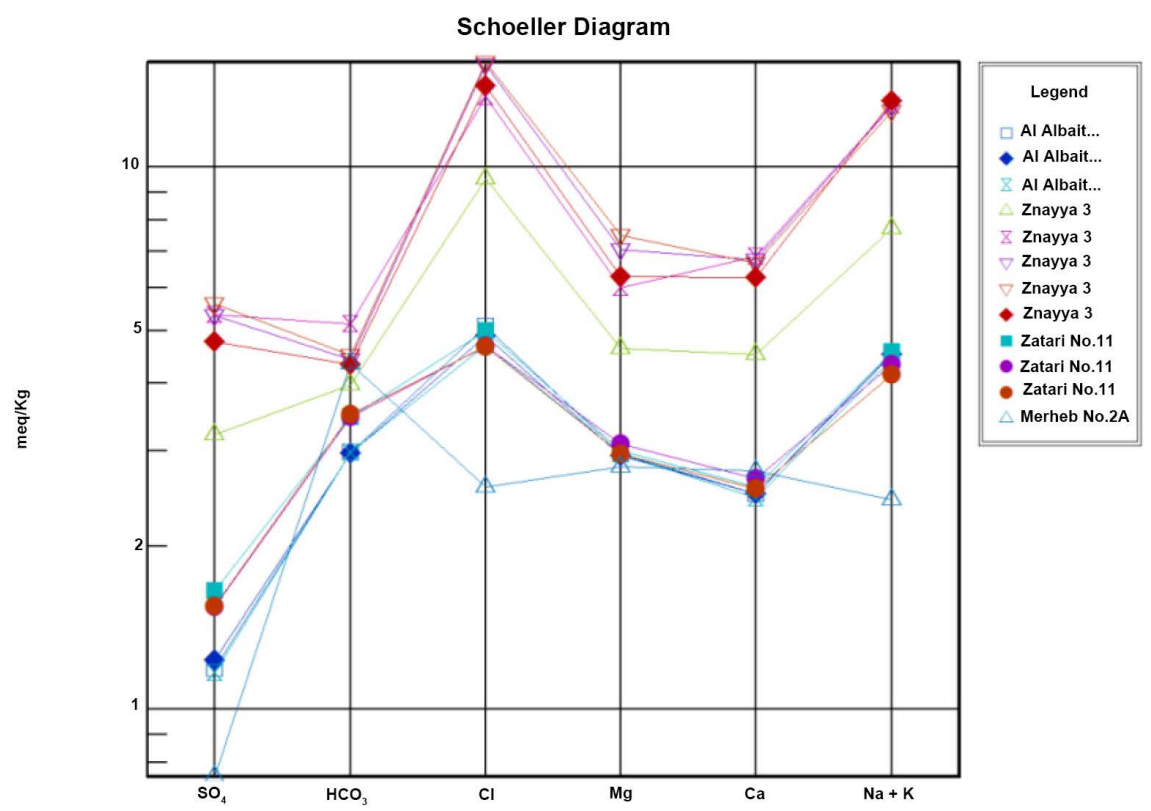

Figure 3. Schoeller diagram showing average composition of major cations anions in $\mathrm{mg} / \mathrm{l}$ and $\mathrm{meq} / \mathrm{l}$ of the groundwater of Mafraq.

as to the origin of the water represented by the analysis and to characterize different water types. Piper divided waters into four basic types according to their placement near the four corners of the diamond. Water that plots at the top of the diamond is high in $\mathrm{Ca}^{2+}+\mathrm{Mg}^{2+}$ and $\mathrm{Cl}^{-}+\mathrm{SO}_{4}^{2-}$, which results in an area of permanent hardness. The water that plots near the left corner is rich in $\mathrm{Ca}^{2+}+$ $\mathrm{Mg}^{2+}$ and $\mathrm{HCO}_{3}^{-}$and is the region of water of temporary hardness. Water plotted at the lower corner of the diamond is primarily composed of alkali carbonates $\left(\mathrm{Na}^{+}+\mathrm{K}^{+}\right.$and $\left.\mathrm{HCO}_{3}^{-}+\mathrm{CO}_{3}^{2-}\right)$. Water lying nears the right-hand side of the diamond considered saline $\left(\mathrm{Na}^{+}+\mathrm{K}^{+}\right.$and $\left.\mathrm{Cl}^{-}+\mathrm{SO}_{4}^{2-}\right)$.

The Mafraq groundwater samples are plotted in Piper Diagram (Figure 4). The figure shows three different groups of samples that have been summarized in Table 1. Most of samples, about 58\% occupy middle upper side of the diamond shape. This group indicates mixed water (chloride-calcium and chloride magnesium water type). $33.3 \%$ of samples occupy the right corner of the diamond shape, where these samples belong to sodiumcloride water type). $8.3 \%$ of the samples located in the left corner of the diamond shape where these samples belong to calcium bicarbonate type.

\subsection{Durov Diagram}

[7] introduced another diagram which provides more information on the hydrochemical facies by helping to identify the water types and it can display some possible geochemical processes that could help in understanding quality of groundwater and its evaluation.

The Durov Diagram for the major cations and anions was plotted using AquaChem software as given in Figure 5. The Duorv plot for Mafraq groundwater 


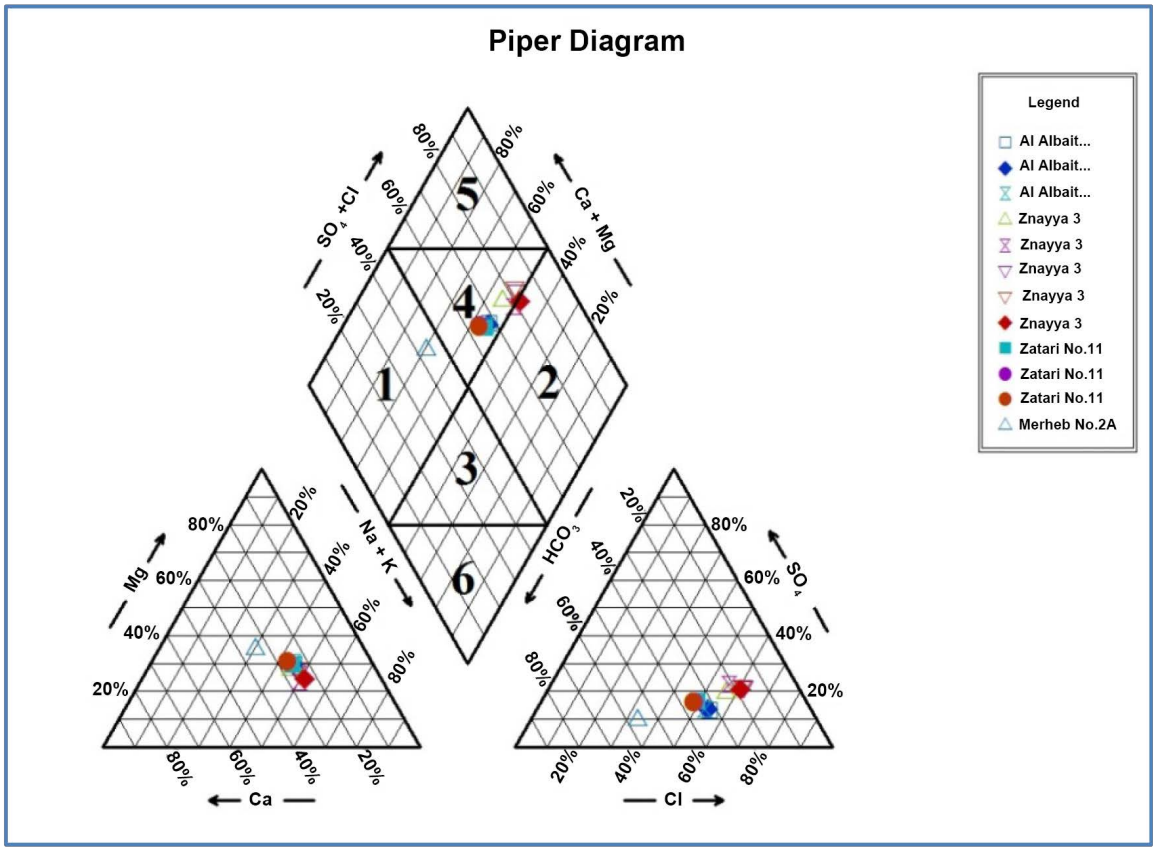

Figure 4. Piper Diagram depicting hydrogeochemical facies of Mafraq groundwater.

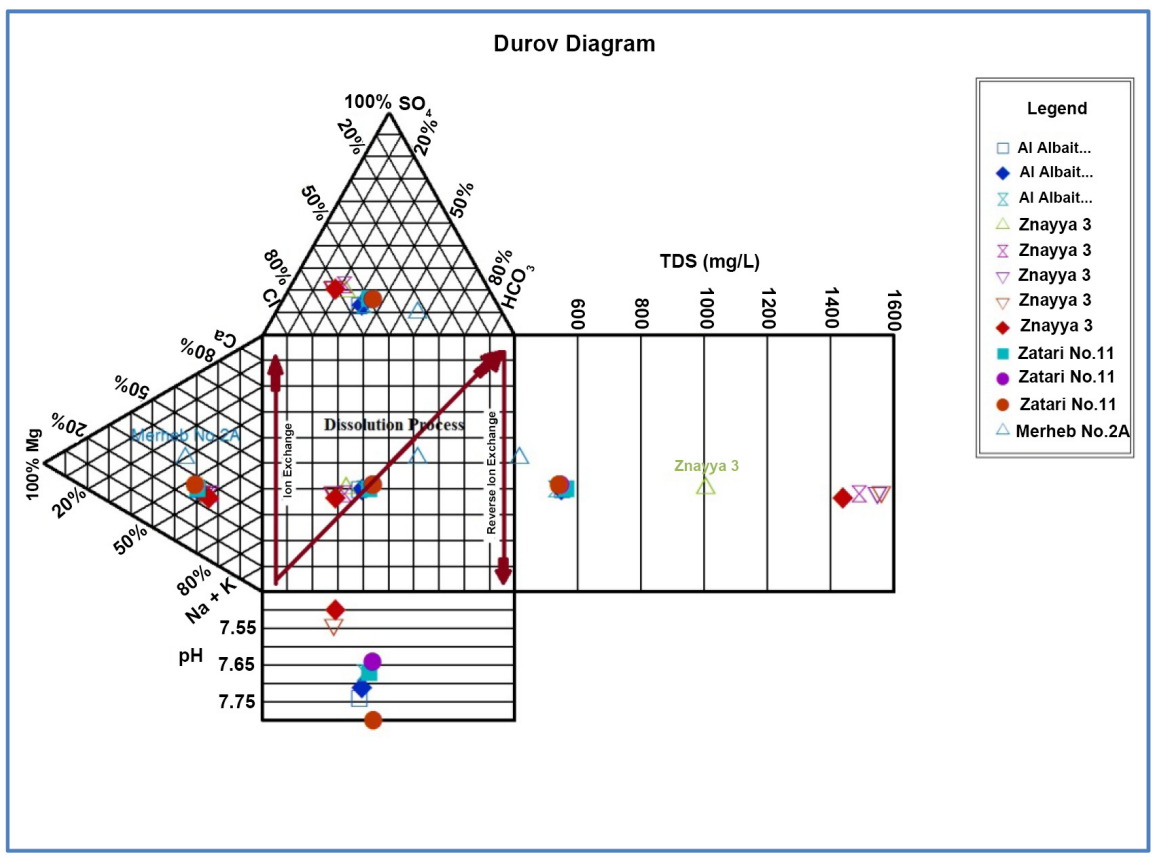

Figure 5. Durov Diagram depicting geochemical processes in Mafraq groundwater.

Table 1. Hydrochemical facies carried out by Piper Diagram.

\begin{tabular}{cccc}
\hline Facies Type & Station & No.of Samples & Percentage \% \\
\hline $\mathrm{CaHCO}_{3}$ & Merhab No. 2A & 1 & 8.3 \\
$\mathrm{NaCl}$ & Znayya 3 & 4 & 33.3 \\
Mixed CaMgCl & $\begin{array}{c}\text { Al Albait (3 Samples), Zatarti } \\
\text { (3 samples) and Znayya (1 sample) }\end{array}$ & 7 & 58.3 \\
\hline
\end{tabular}


samples indicates that most of the samples are in the phase of mixing, dissolution. The $\mathrm{pH}$ part of the plot reveals that groundwater in study area is alkaline which is favored for drinking. The total dissolve solid for most of groundwater samples lies in the range of drinking water standards adapted in Jordan except for Znayya 3 Wells the TDS reach more than $1500 \mathrm{mg} / \mathrm{L}$.

\section{Groundwater Quality}

Human welfare is directly linked to water quality and quantities, chemistry of the groundwater have been used for the evaluation of quality of water for drinking, domestic and irrigation purposes. It was estimated that about $1000 \mathrm{~km}^{3}$ of the world's aggregated groundwater is abstracted annually.

\subsection{Water Quality for Drinking Purposes}

Chemical analyses define the type and significance of various chemicals present in water, the standards for water constituents used to evaluate the suitability of water for drinking and domestic purposes are more precautionary than those that would be applied to water for other purposes such as irrigations or industrial use.

The maximum permissible limits for water standard by World Health Organization [8] have been added in Table 2. The average of samples with contents their location in study area has also been given.

It is observed from this table that, out of 4 groundwater average samples, only 1 sample have shown TDS values more than maximum permissible limit of 1000 $\mathrm{mg} / \mathrm{l}$ at Znayya 3. As also seen, all samples locations have nitrate concentration higher than the permissible limit. Generally, the groundwater in the most of study area is suitable for drinking purposes except for Znayya 3.

\subsection{Water Quality for Irrigation Purposes}

Excessive Salts may harm plant growth physically by limiting the uptake of water through modification of osmotic processes, or chemically by metabolic reactions such as those caused by toxic constituents [9]. In this study, the discussion of water quality for irrigation is mainly based on the following factors:

\section{Sodium Adsorption Ratio (SAR)}

The relation between $\mathrm{Na}$ and $\mathrm{Ca}+\mathrm{Mg}$ ion content affects the physical properties of soil. This relation can be expressed by sodium adsorption ratios (SAR). The higher the sodium adsorption ratio, then less suitable the water is for irrigation, that is implies that sodium in the irrigation water may re-place calcium and magnesium ions in the soil, which will cause long term damage to the soil structure. It is defined by the suitability of water irrigation is a function of both specific conductance and SAR, the relations between specific conductance and SAR values from the four sites in Mafraq province were graphically presented in Wilcox diagram in Figure 6, where the ion concentrations are expressed in equivalent per million (epm). Two Factors used to show the suitability of water 
Table 2. Sample average concentration compare to [9].

\begin{tabular}{cccccc}
\hline \multicolumn{2}{c}{ World Health Organization } & \multicolumn{4}{c}{ Sampling station average concentrations $(\mathrm{mg} / \mathrm{L})$} \\
\hline Parameter & $\begin{array}{c}\text { Maximum } \\
\text { Permissible }\end{array}$ & Al Albait & Znayya 3 & Zatarti & $\begin{array}{c}\text { Merhab No. } \\
2 \mathrm{~A}\end{array}$ \\
\hline $\mathrm{TDS}(\mathrm{mg} / \mathrm{L})$ & 1000 & 542 & 1409 & 764 & 415 \\
$\mathrm{Na}(\mathrm{mg} / \mathrm{L})$ & 200 & 102 & 270 & 141 & 55 \\
$\mathrm{Mg}(\mathrm{mg} / \mathrm{L})$ & 150 & 36 & 76 & 46 & 34 \\
$\mathrm{NO}_{3}(\mathrm{mg} / \mathrm{L})$ & 10 & 32 & 80 & 27 & 9.9 \\
$\mathrm{Cl}_{(\mathrm{mg} / \mathrm{L})}$ & 250 & 173 & 483 & 248 & 91 \\
$\mathrm{SO}_{4}(\mathrm{mg} / \mathrm{L})$ & 250 & 57 & 233 & 115 & 36
\end{tabular}

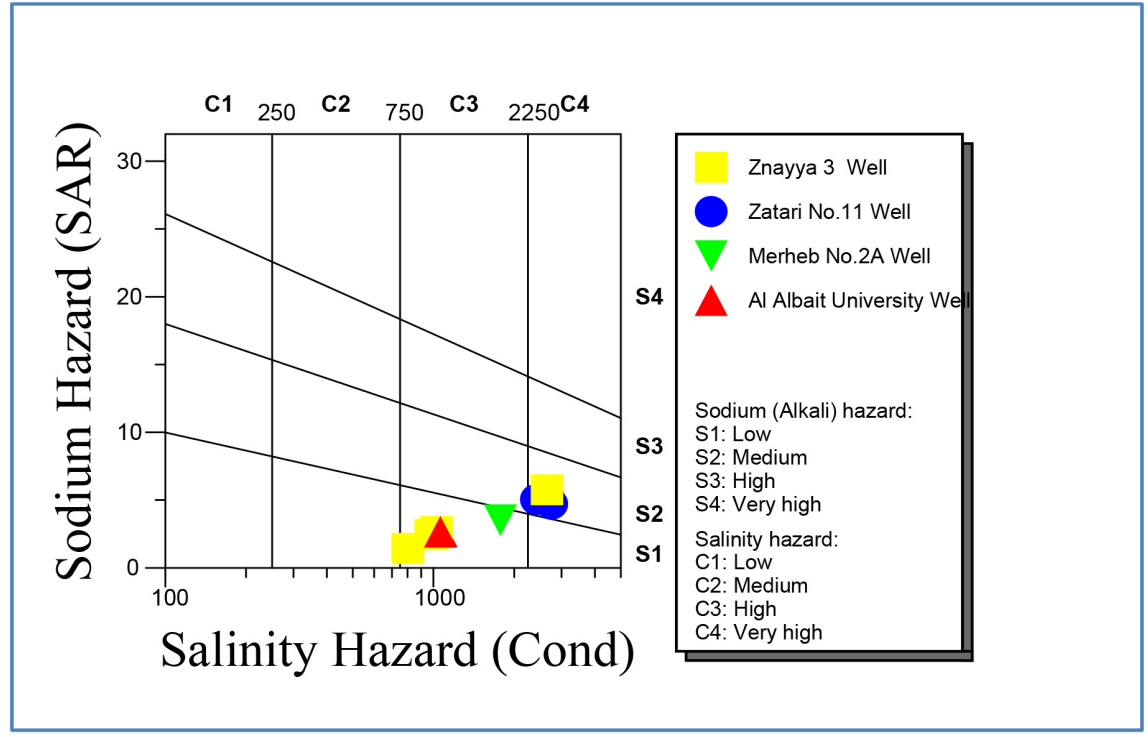

Figure 6. SAR values from the four sites in Mafraq province were graphically presented in.

for irrigation are SAR and specific conductance. These two Factors are combined to make the classifications shown below. To make the classifications shown below.

Salinity hazard dividing points are 250, 750 and $2250 \mu \mathrm{moh}$, resulting in four categories: Low salinity water (C1), Medium salinity water (C2), High salinity water (C3) and Very high salinity water (C4).

The Wilcox diagram in Figure 6 shows that about $33 \%$ of the samples fall into C4-S2 class with very high salinity and medium sodium hazard and the rest of the samples fall into C3-S1 with high salinity and low hazard. This water cannot be used on soil without special management for salinity control in well Znayya 3; plants with good salt tolerance should be planted in the Mafraq province around this area.

\section{Conclusions and Recommendations}

Mafraq province suffers from increase demand of groundwater due to rapid in- 
crease in population of the Syrian refugee. In the present study, 12 ground water samples were collected from 4 locations of Mafraq Province north of Jordan. This study recommends more detail study using geochemical models to trace the sources of high nitrate concentration in groundwater. Interpretation of hydro-chemical analysis reveals that:

The $\mathrm{pH}$ values range between 7.5 and 7.9 with mean value of 7.7 and EC values range from $1562 \mu \mathrm{s} / \mathrm{cm}$ in Znyya 3 Location to $415 \mu \mathrm{s} / \mathrm{cm}$ in Merhab.

Geochemistry of groundwater displays $\mathrm{Na}>\mathrm{Ca}>\mathrm{Mg}>\mathrm{K}$ and $\mathrm{Cl}>\mathrm{HCO}_{3}>$ $\mathrm{SO}_{4}$ trend.

The major element's data were plotted on Piper's diagram indicated that, three hydrogeochemical type facies were identified that $58.3 \%$ of the samples are mixed $\mathrm{CAMg} \mathrm{Cl}$ water type, $33.3 \%$ of them belong to the $\mathrm{NaCl}$ water type and $8.3 \%$ for $\mathrm{CaHCO}_{3}$ type.

The Duorv plot for groundwater samples indicates that most of the samples are in the phase of mixing dissolution.

Comparisons of data with [8] standards for drinking water indicate that the groundwater in the most of study area is suitable for drinking purposes except Znayya 3.

The Wilcox diagram shows that about $67 \%$ of groundwater samples are located in C4-S1 class and about 33\% of the samples fall into C4-S2 class.

\section{Conflicts of Interest}

The authors declare no conflicts of interest regarding the publication of this paper.

\section{References}

[1] Bender, F. (1975) Geology of the Arabian Peninsula-Jordan. United States Geological Survey Professional Paper No. 560-1, Washington DC, 36 p.

https://doi.org/10.3133/pp560I

[2] Abed, A.M. (2000) Geology of Jordan. Jordanian Geologists Association, Amman.

[3] Obeidat, A.M. and Rimawi, O. (2017) Characteristics and Genesis of the Groundwater Resources Associated with Oil Shale Deposits in the Azraqand Harrana Basins, Jordan. Journal of Water Resource and Protection, 9, 121-138. https://doi.org/10.4236/jwarp.2017.92010

[4] APHA (1995) Standard Method for the Examination of Water and Wastewater. 19th Edition, American Public Health Association, Washington DC.

[5] Schoeller, H. (1960) Salinity of Groundwater, Evapotranspiration and Recharge of Aquifers. IASH Pulls., France.

[6] Piper, A.M. (1944) A Graphic Procedure in the Geochemical Interpretation of Water Analysis. American Geophysical Union Transactions, 25, 914-923. https://doi.org/10.1029/TR025i006p00914

[7] Durov, S.A. (1948) Natural Waters and Graphical Representation of Their Composition. Doklady Akademii Nauk, USSR, 59, 87-90.

[8] WHO (2011) Gide Lines for Drinking Water Quality. Fourth Edition, Vol. 1, WHO Library Cataloguing-in-Publication Data, Geneva. 
[9] Abdellatef, S.A., Ohi, A., Nabatame, T. and Taniguchi, A. (2013) The Effect of Physical and Chemical Cues on Hepatocellular Function and Morphology. International Journal of Molecular Sciences, 15, 4299-4317.

https://doi.org/10.3390/ijms15034299 